\title{
The individualisation of health in late modernity
}

\section{Tolvhed, Helena}

Routledge

2018

Tolvhed , H \& Hakola , O 2018 , The individualisation of health in late modernity . in J

Kananen , S Bergenheim \& M Wessel (eds), Conceptualising Public Health : Historical and

Contemporary Struggles over Key Concepts . Routledge Studies in Public Health ,

Routledge , Abingdon , pp. 190-203 . https://doi.org/10.4324/9781315178271-12

http://hdl.handle.net/10138/321955

https://doi.org/10.4324/9781315178271-12

acceptedVersion

Downloaded from Helda, University of Helsinki institutional repository.

This is an electronic reprint of the original article.

This reprint may differ from the original in pagination and typographic detail.

Please cite the original version. 


\title{
11. The Individualisation of Health in Late Modernity
}

\author{
Helena Tolvhed \& Outi Hakola
}

\section{Introduction}

The maintenance of a healthy population has been a major goal for social and welfare policies in the Nordic countries. During the twentieth century, the health status of the individual was not considered a strictly private concern but part of the general collective capital, and medical expertise and research had an important role in constructing notions of societal development. ${ }^{1}$ In the late twentieth century, however, the emphasis on consumption and individual expression was followed by an individualisation of health. The prevention of illness has increasingly come to be understood as the responsibility of each individual citizen rather than that of the state, and lifestyle management has replaced traditional structural and economic explanations of public health concerns. ${ }^{2}$ However, this emphasis on illness prevention and individual responsibility for one's own health is not entirely new for the post-1970 society; as Karin Johannisson has pointed out, the Swedish welfare state presupposed and relied on the efforts of individuals to improve their own health and was built to support and facilitate these efforts. ${ }^{3}$ The individualisation of health is a general development in the Western world, but in the Nordic countries, it has fundamentally changed the logic of the welfare state at an ideological level. During the last decades, the state-run Swedish and Finnish public health regimes, which had close ties to the national sports movements, have been supplemented and partly replaced by a commercial health and fitness industry whose agenda is largely set by private operators. This industry includes a booming market for health and training-magazines, as well as internet fora, taking over the role as primary advisor and regulator on health maintenance. The development means that health is increasingly managed without the government's involvement.

In this chapter, we study new norms and discourses in health management, and the meanings related to it, through Swedish health and fitness magazines and periodicals and Finnish tabloid health journalism. Central to the methodology is the comparison of representations and the ways in which the reader is addressed. When analysing and scrutinising representations and values related to health, we give special attention to gender issues, since men and women have faced rather different expectations. Late modernity introduced new gender ideals in the form of the physically active and well-trained female, as well as the appearance-oriented man. For women, 
this stands in stark contrast against a history where modern sports during the nineteenth and well into the twentieth centuries were often considered incompatible with conceptions of respectable femininity. Women were warned of the physically and mentally harmful and masculinising effects of sport and strenuous physical activities. ${ }^{4}$ In today's field of health and fitness, however, women no doubt occupy a central position as subjects/consumers. Hence, gender needs to be taken into account when analysing how the media constructs, normalises and challenges different understandings of health.

An interest in health and diet is far from new. Likewise, prescriptions of body management and diet and its association with moral life have existed for a long time. What is new, we suggest, is the extent to which this is part of popular and commercial culture in a neoliberal economy targeting the individual consumer. We will illustrate how health journalism in Sweden and Finland reflects Western processes of individualisation, commercialisation, feminisation and depoliticisation of health. The impact of this is underlined by the growth of the health and trainingmagazine market (including supplements in tabloids), and later on social media, from the 1980s onwards, with more and more niches and titles on the market. ${ }^{5}$ Our analysis of the individualisation of health is framed by the concept of healthism, which is discussed in relation to changes in power relations and citizenship.

\section{'Healthism' and bio-politics in late modernity}

Robert Crawford has identified an ideology of 'healthism' - where health and a fit body are lifestyle markers and metaphors for morality and a good life in late modern society. Subjects are constructed as autonomous agents responsible for their own wellbeing, without considering social and economic determinants. Health has, according to Crawford, become a "super value", implicating not only the absence of sickness but also happiness, sense of self, ability to function, and productivity. ${ }^{6}$

The concept of healthism can be connected to Michel Foucault's theoretical concept of biopolitics, a regulating regime where human life is managed through knowledge and power, and the related processes of subjectivity. ${ }^{7}$ Foucault argued that the character of bio-politics changed during the twentieth century, from the disciplinary regimes of families, hospitals, schools and factories towards more sophisticated techniques of governing. In late modern consumer culture, power primarily works through stimulation and internalised self-monitoring, influencing the way people think, feel and perceive. ${ }^{8}$ 
Late modern governance, hence, works not through the imposing of constraints but through shaping a citizen capable of exercising regulated freedom - conceptualised as 'free choice'. Here, subjects actively participate in the process of governance. In the new modes of regulating health, individuals are addressed on the assumption that they want to be healthy, not least due to the synonymous use of healthiness and happiness, and enjoined to seek out the ways of living most likely to promote their own health. Experts instruct us as to how to be healthy, advertisers picture the appropriate actions and fulfilments, and entrepreneurs develop a market for health. ${ }^{9}$

The concept of 'free choice' is central in the rise of neo-liberalism since the mid-1970s. ${ }^{10}$ An underlying assumption within the 'healthist paradigm' is that illness is (largely) preventable and that individuals have a choice in matters of health. ${ }^{11}$ Whereas the 'healthy' body is perceived as a reflection of self-control and a 'healthy' inner world of the subject, the unhealthy body is read as a moral and aesthetic personal failure. ${ }^{12}$ The body is constructed as a project, in need of constant maintenance and open to reconstruction and improvement - it is forever unfinished. ${ }^{13} \mathrm{With}$ the increasing demand for self-management, critical voices in public debate have noted a growing 'health stress' and body fixation, and question a development where the employee's health becomes a concern for employers and a means to compete in today's "flexible labour market". ${ }^{14}$

Self-management and individualisation of training has been connected to a more general individualisation of Western culture. ${ }^{15}$ Since the 1970s, alternatives to the traditional sport movements have emerged: jogging/running and exercising at gyms have transformed from rather marginal phenomena into being part of everyday culture. ${ }^{16}$ Late modern physical culture is individualist and social interaction, even in gym classes, is often limited. ${ }^{17} \mathrm{New}$ forms of exercise, body treatments, diets and wellbeing strategies appear constantly, and health coaches and personal trainers are growing professions. This expanding market includes health media - magazines, newspapers and online media - which circulate the latest ideas of diet and exercise, news of health-related studies, and changing trends in well-being. The number of niches seems to keep growing constantly: for different kinds of diets and 'healthy eating', yoga, triathlon or weighttraining, running for women over 40, and so on. Athletes and various celebrities publish books and talk on television shows about their healthy living and give their best exercise tips.

Offering advice on how to live, eat and exercise, the health media is a useful source in order to capture a broader discourse on health. In its own way, the health media participates in Foucauldian bio-politics and rationalisation of social power by addressing citizens who are supposed to use the available information for their own best interests. ${ }^{18}$ In this chapter, we approach the changing 
social values and politics of health and healthism as cultural processes where the media is regarded as a co-creator of reality and of human identities. ${ }^{19}$ We will start our analysis from Swedish health magazines, and continue with Finnish tabloids before turning to a discussion on gender and health.

\section{The Swedish Journal of Health 1960-2010}

Tidskrift för Hälsa (Journal of Health, 1940-) is the oldest still appearing Swedish periodical specifically dealing with the subject of health. ${ }^{20}$ It was the only magazine on the Swedish market directed at the general public focusing on the subject of healthy living until the introduction of iForm in $1987 .{ }^{21}$ The analysis here is based on the volumes from the years 1960, 1970, 1980, 1990, 2000 and 2010.

In the volumes of 1960 and 1970, the magazine takes a firm position on threats to the individual's health as well as to society as a whole. Health was to be achieved through natural living and diet, and the magazine favoured bio-dynamic and organic farming, eating raw vegetables and wholegrain food, animal protection, alternative medicine, hiking and gymnastics. Articles and editorials argue against environmental toxins and chemicals, artificial sweeteners, sugar, fluoride, nuclear power, processed food, war, tobacco, alcohol and world famine. ${ }^{22}$ The covers show pictures of natural scenery, photos of children or health movement profiles. The ways of living of indigenous people, at times also the Vikings and "Eastern wisdom", is idealised and used for critiquing modern society's materialism, shallowness and environmental degradation. Industrial meat and egg production is regarded as both morally wrong and wasteful of resources. ${ }^{23}$ Critique of the consequences of the global market economy is also voiced; for example, an article from 1970 demonstrates the headline "Everything we don't need is available to buy" 24 , and an editorial against nuclear power critiques "short-sighted economic interests". ${ }^{25}$

Hence, in 1960 and 1970, readers were addressed as a kind of vanguard group of the "health conscious', urged to take action and lead the way for a general reform and betterment of the Swedish population. Concepts such as "people" (folk), "public/people's health" (folkhälsa) or "the health standard" (hälsonivå) of the population are commonly referred to in the articles. Editorials recommend readers to arrange marches and other activities for the general public, and sports activities in order to make youth interested in health promotion. ${ }^{26}$ Hence, a message of the responsibility for one's own individual health was clear, but the ultimate cause and goal was wider: a national - and by extension global - reform of the people. 
In the journal's volume 1980, the cover photographs have changed completely, with the majority now showing only food. The covers hence reflect a shift towards consumer advice, and away from social and political commentary and critique; articles commenting on society, economy and environment have now almost disappeared. ${ }^{27}$ Journal of Health had adopted a narrower focus on healthy eating, presenting the nutritional value of different foods as well as the occurrence and dangers of food additives and preservatives. Articles on how to cure various forms of disease with the right diet are frequent. The cover pages exhibit short quotes with an urging and direct reader address, "End your bad habits", "How to treat stomach pains", "How to handle you back", "How to get better sleep" and "The best diet from morning to evening". From a previous broad definition of health, embedded in a social and political context, the focus of journal had moved towards the management of individual health.

Journal of Health 1990 (now only called Health) features another noticeable change: a strong focus on weight-loss and the use of smiling, posing and slim female models on most of the cover photos (face or full/part body), making it look similar to general women's magazines. The first issue shows a jumping model holding the waistband of her trousers, which are obviously too big for her. The main headline reads "The ten best ways to slim down". ${ }^{28}$ Other examples of main headlines on the magazine covers of this volume are "Become slim without dieting", "Great shape after 40" and "Lose weight without dieting". Calories and "slim food" are also in focus in the recipe-section - it seems that slim now equals healthy. Like in 1980, health is constructed as a decontextualised and de-politicised phenomenon; the content is oriented towards prescribing ways for the individual care of one's own body. The trimmed (female) body has now emerged as the prime manifestation of health. Health is now understood as an individual responsibility as well as a feminised field. ${ }^{29}$

The use of female - slim, smiling and usually white - models on the cover photos persists in the magazine's volumes 2000 and 2010. The focus is on healthy food, but also on alternative medicine and therapies, together with mental balance and stress relief methods, such as meditation.

Alternative medicine and "mainstream" medicine are presented as complementary, and there is no mentioning of any conflict between the two fields. The content is more explicitly feminised, with sections advising on nail, skin and hair care. Like in the 1960 and 1970 volumes, the magazine recommends natural and ecological products and food without additives, but there are no longer any references to global political and economic conditions or structures impacting on health.

Weight loss and weight maintenance are represented as central aspects of health, and exercise has become a more important theme. 
The urging way of addressing the reader and the imperative to change one's behaviour is continuously present in Journal of Health during the studied time period. However, from 1980 onwards, the focus shifts from changing the world to perspectives on how to take care of one's own body and avoid hazards to personal health. The organic view of human beings as part of a world society and the ecosystem is replaced by an exclusive attention to the individual body. This implies disconnecting from social and political contexts; these no longer appear relevant to the conceptualisation of health. The shift is also underlined by the fact that we are dealing with a commercially viable genre with new magazines starting up during the 1980s, 1990s and 2000s. In the magazine's volumes from 1960 and 1970, the reader is urged to see the maintaining of their own fitness and health as a duty of citizenship, which would benefit both the nation and humanity. The focus shifts from social citizenship with obligations deriving from membership of a collective body to an individualistic discourse emphasising personal gains and making informed consumer choices. ${ }^{30}$ As Wendy Brown has formulated in discussing the "post-political" state: "The model neo-liberal citizen is one who strategizes for her/himself among various social, political and economic options, not one who strives with others to alter or organize these options". ${ }^{31}$

\section{Finnish tabloids 2010-2016}

In the 1980s and 1990s, ideas of individualism and rise of neo-liberalism slowly emerged in Finland as well. State documents and reports that had previously emphasised the nation's role in active social politics began addressing individuals as subjects involved in a constant process of developing themselves, similarly to self-help literature. ${ }^{32}$ At the same time, health-inspired rhetoric appeared in Finnish magazines in the 1980s, and in the 1990s, consumerism increased its importance. Earlier values of community and shared responsibility were at least partially replaced when the discussion moved towards personal choices in the fields of health, diet and exercising. ${ }^{33}$ Yet, even in contemporary Finnish popular media, the state's or community's responsibility and the individual's responsibility continue to coexist. Pertti Suhonen, for example, argues that health as a value has increasing importance in Finnish culture and society. This is reflected in people's beliefs, but also in the increasing amount of official health education, health marketing and health communication. ${ }^{34}$

In the following, health journalism in contemporary Finnish tabloids Ilta-Sanomat and Iltalehti is analysed through "wellbeing and health" articles published between 2010 and 2016. The focus is on health discussions involving mortality. The mortality rate ${ }^{35}$ and the life expectancy of people ${ }^{36}$ are ways to compare the state of health between nations, and they may be regarded as proxies for quality of life, social equality and peace. Thus, when a newspaper article dealing with health 
chooses to emphasise the quantifiable mortality rate, national success is related to personal health, and personal health becomes a social concern as well. This practice exemplifies what Nikolas Rose and Carlos Novas refer to as "biological citizenship". Late modern citizens are made aware of and evaluated according to their biological conditions, including both medical conditions and vitality, such as health and exercise. ${ }^{37}$ Thus, the citizens' responsibility is to actively shape their lives through acts of choice.

An individual's health and wellbeing is not just about having or giving the right kind of information; it is also about emotions, experiences and a sense of self. Health-related articles in Ilta-Sanomat and Iltalehti indeed emphasise the importance of choice, underlined by addressing the reader with phrase "you" - your health, your actions. They also address the readers by two main types of discourse. The first, more common one, is threat - the articles provide information on unhealthy habits, such as smoking or immobility. This approach invokes the reader to feel guilty about their lifestyle choices by emphasising negative effects. ${ }^{38}$ For example, in a story about the dangers of being overweight, Ilta-Sanomat proclaims "The harsh truth: all extra weight shortens life-span", and continues to list negative consequences such as diabetes, cancers, heart problems etc. $^{39}$

The other strategy to address readers relies on hope - the articles provide information on how some habits make you healthy, and encourage the reader to continue, or in some cases to acquire, these habits. For example, Ilta-Sanomat greets its audiences: "Good news! A couple of hours of weekly exercise is enough to increase life expectancy." 40 The hopeful strategy assumes the reader actively seeks to increase their own wellness, health and quality of life. Sometimes articles are also open to different kinds of interpretations - the readers can think of the same story as educational or alternatively, as showing a way to a good and happy life.

In tabloid journalism, both threats and hopes are backed by information, expert commentary, and scientific facts. The difference to openly commercial magazines can be explained by different understandings of journalism - magazines publish stories, whereas tabloids define their articles as "news". Thus, sources are of importance. Ulla Järvi has identified three styles of argumentation in Finnish health communication: scientific argumentation built on research, economic reasoning regarding the costs of unhealthy lifestyles for the society, and human argumentation based on our consciousness of mortality. ${ }^{41}$ The Finnish tabloids utilise these health communication strategies, in particular the scientific approach (many health stories refer to scientific research, statistics, or the expertise of doctors or researchers). The economic communication strategy is the rarest form, 
although sometimes health care costs are presented as the amount of tax payers' money spent on health care, and especially on health issues that could have been minimised by different lifestyle choices or preventive practices. ${ }^{42}$ The third argumentation type, human interest, is reflected in stories based on personal experience, such as testimonials about how 'I' lost weight or quit smoking. The human argumentation utilises people's fear of dying, pain, sickness and loss of autonomy by playing with threats and hope in an intimate fashion. Human argumentation also plays with beauty ideals which add to questions of vitality and wellbeing. For example, when discussing the dangers of sun bathing, Ilta-Sanomat reminds the readers about the paradoxes of mixed beauty ideals - beautiful tanned skin leads to undesired wrinkles in older age. ${ }^{43}$ Here, fitness and beauty support the mortality strategy to create an image of desirable life.

Analysing the articles which use mortality as a narrative strategy, two major issues become apparent. First of all, in these articles, health is understood in a wide sense. It is related to lifestyles, whereas illnesses are framed as consequences of undesired individual choices. The wellness section of the tabloids, unsurprisingly, deals with nutrition, weight issues, exercise, and addictive habits such as drinking alcohol or coffee, using drugs or smoking. Yet, the stories also include other issues. Wellbeing can be achieved by owning a dog, getting married, being social and active, or by winning a Nobel Prize. Individual choices have indeed become part of healthism. The most varied aspects of life can be understood in terms of health. The self-management of one's health and wellness is represented as a condition for high quality of long life. In a sense, the articles convert social norms into personal desires - setting the cultural agenda and shaping human subjectivity in a context of a consumer society.

Secondly, mortality is used in the context of calculative measures. The articles sometimes count the years certain habits either give or take from one's life. Finnish tabloids, for instance, have observed how childhood obesity threatens increasing life expectancies in Western countries, ${ }^{44}$ how four lifestyle changes give ten more years to over-65-year-olds, ${ }^{45}$ and how a firm handshake increases the lifespan. ${ }^{46} \mathrm{Also}$, several articles include tests in a spirit of participatory health communication: with the help of questionnaires or activities, readers can calculate their own life expectancy and test the sustainability of their lifestyle choices. These articles suggest that the success of health management can be measured in terms of an increase in life expectancy and the length of a potentially productive working career.

Although the information about life expectancy can be useful for 'shopping' between lifestyles, this argumentation style is also related to public health. Alan Petersen and Deborah Lupton have 
argued that already since the nineteenth century, public health projects have relied upon “"scientific' and 'rational' methods of monitoring, measuring and regulating the population", 47 This bio-political strategy focuses more on risk groups than individuals, and uses biostatistics, such as life expectancy statistics, to create an idea of factual or objective information. ${ }^{48}$ Similarly, Finnish tabloids do not represent health issues as intertwined or individual choices as a part of a complex entity. Instead, the presented issues encourage individual choices and actions, and the same logic places the responsibility upon the individual, instead of upon "the population" or "the public", which are framed as bearing the consequences of individual choices.

By constructing health as something that can be measured, it becomes associated with productivity. The quantification of health creates a narrative of a 'good life' by establishing the increase of life expectancy as an ultimate goal. An extended lifespan becomes equated with being an active and successful individual. The underlying messages are clear; in order to have a good life and in order to be a happy and responsible citizen, one should take care of one's health. This new form of healthy and responsible citizenship requires diligence, self-control and hard work.

\section{Feminisation of the health and fitness media}

Historically, new gender ideals in late modernity - the physically active and well-trained woman and the appearance-oriented man - are closely aligned with diet and exercise practices. Gender permeates forms of exercise practices, as well as media representations of body and health. ${ }^{49}$ Women have often been expected to be more conscious of health and fitness in comparison to men, due to the special role of care-givers and mothers, where women are seen responsible for providing health care and education, as well as a sound home environment. For example, Finnish health and fitness magazines, such as Kauneus \& Terveys, Kunto Plus and Voi hyvin, define their target audiences as (middle-class) women by claiming to write for "active women" who take care of their fitness, beauty, health and wellbeing. ${ }^{50}$

Lund Kirkegaard has identified career-orientated middle-class women as a core group for the fitness industry since the 1980s, with Jane Fonda's rise as an exercise icon. The gym offers a variety of different classes and does not demand as much coordination with others as sports usually do. Hence, it could more easily fit into the busy everyday life of work and family life. ${ }^{51}$ Regarded against a history where muscles and physical strength have often been perceived as unfeminine and unwanted for the female body, the rise of the fit female body ideal could be seen as emancipatory, as symbolising activity and power. But feminist researchers have questioned the 
emancipatory potential, pointing out the limiting and harmful bodily norms of the fit and toned ideal. $^{52}$

In a study of the Swedish health magazine iForm from 1987, 1997 and 2007, Helena Tolvhed identifies an individualist discourse getting more prominent during the time period. Traditional sports and play are replaced by more 'rational' and time-effective forms of exercise that cut out the social elements present in sport and maximise physical exercise. The very definition of health becomes narrower; areas such as sex and relationships have disappeared from the magazine in 2007, as have more general educational articles on the body. Instead, the focus on diet and exercise has increased. ${ }^{53}$ The female models that are used to represent "health" are conventionally beautiful, smiling, white and predominately thin, rather than obviously muscular. This, Tolvhed concludes, limits the destabilising potential of the "fit" woman in iForm. She might have more "toned" arms, but today's mediatised representation of the "fit" and "healthy" woman still conforms to a narrow and largely stereotypical ideal of femininity. Through the advice given on how to eat, how to exercise, and how to lose weight, the body is constructed as inherently flawed, constantly in need of work. The way to avoid becoming unfit and unattractive is to consume and to become more knowledgeable about exercise and healthy eating - this is the road to success and happiness. ${ }^{54}$ The responsibility for success as well as failures is the individual woman's own, and no attention is paid to the impact of limiting power structures, for example related to gender or class. The visual representation of physical health in health magazines and tabloids is obviously "closely aligned with the cultural conventions of beauty", as Christy Newman has put it. ${ }^{55}$

Finnish tabloids also contribute to a feminisation of healthism with their imagery. In general, tabloids aim to address all genders, and most health articles do not differentiate between genders, except in cases where the article deals with gendered phenomena, such as motherhood or increased health problems within the male population. Yet, the visualisation of the stories reveals some degree of feminisation. The photos used in the health-related articles can be divided into four categories: photos of women, men, both or unidentified genders, such as close-up pictures of hands or feet, and pictures without people in them. The least popular option is to use pictures of only men which are used in connection to stories about athletics and work life. The third category includes pictures without any people, and these stories often deal with nutritional information, stories about medicines and vaccinations, and occasional stories about climate issues, gambling, prisoners, city and work lives. 
The second most popular category does not differentiate clearly between genders. These pictures either include both men and women (stories about sex life, divorce, and about getting old), or the gender is unclear in the picture (pictures about hands, feet etc.) when the story narrates overeating, work life and handshaking issues. The most popular category includes women. Here, a distinction between unattractive and attractive women is visible. Unattractive women are overweight, messy, and poorly dressed, whereas attractive women are white, slim, well-dressed, and well-groomed. The first category illustrates health risks related to overeating and smoking, whereas conventionally beautiful female models represent issues such as exercising, sunbathing, and stories about wellbeing and motherhood, as well as stories about how being nice and happy increases your life expectancy. These categories reveal how men are connected to working life or athletics, whereas women's health issues are more concentrated on their body images and body management.

Consumer culture encourages self-reflection, with media and advertising providing pictures of (mainly young and female) bodies that show consumers what they can, and should, become. It represents happy, healthy and beautiful people as role models for consumers to aspire towards. ${ }^{56}$ In a gendered healthist culture, the success of women, in particular, is increasingly assessed in terms of health, fitness and wellbeing instead of other areas of life. There is a noticeable overlap between the meanings of health and beauty that works in both directions; health is understood as equalling a slim, toned body, and looking good becomes equal to being healthy.

\section{Conclusions}

The post-war welfare states relied on an authoritarian expert community and the assumption that there was a right way to act. In contrast, the late modern health market is inhabited by different kinds of 'experts', such as dieticians, personal trainers, health or life coaches, not only scientists and doctors - and there is no official authority present to sort out the flurry of advice, treatments and methods. The journalist or magazine generally does not have a consistent perspective, but functions in accordance with the principles of free market and identification, rather than traditional medical authority. Instead of a critical reviewer, the health media journalist is a mediator and supplier of research findings and advice from different 'experts', leaving the reader 'free to choose'. Being healthy has become a private concern and responsibility, albeit one that is simultaneously constructed as a prerequisite in order to be an acceptable member of the sociocultural community. On a normative or ideological level, which has here been examined through health media, the social support system seems to have been taken out of the equation. The creation and maintenance of health is, instead, to be achieved through consumption and making the right 
choices in diet and exercise. In the increasing mediatisation of health management, health has become something that can be filtered, understood, controlled, shared, and communicated through media practices. ${ }^{57}$

In a time period of "retreat from welfare interventionism and of reaffirmation of the importance of 'markets' as regulators of economic activity", the concept of rights begins to appear limited and untenable. ${ }^{58}$ Yet, the new modes of regulating health, building on self-management and the discourse of freedom of choice, tend to assume that everyone has same access, ability and skills to understand and relate to the complex and at times paradoxical health messages available. As discussed above, this also limits the emancipatory potential of the 'fit' and 'healthy' woman. While a physically active lifestyle and 'toned' muscles are historically new elements as far as ideal femininity goes, the (female) body is still constructed as being in need of work and change, and in accordance with narrow conceptualisations of female beauty.

Health media contains a broad and multifaceted range of news and advice on health, weight-loss and exercise. The advice offered sometimes seems paradoxical, but, within a neoliberal paradigm, where consumers choose 'freely' between different options, it actually makes complete sense. Rather than subjects defined or supported by the state, citizens are constructed as rational, active and responsible consumers and opportunists who participate in the national project through competitive and free markets. These subject-citizens consume health services and create their own wellbeing. Similarly, any problems related to health or wellbeing appears to be caused by an inability to control one's own life. ${ }^{59}$ The health and fitness media capitalises on this idea of choice, by offering information about different services, products and diet advice. This is a definition of freedom that hides the fact that not everyone has the same opportunities - because of variations in place of residence, different bodily abilities/medical conditions, educational or social and financial circumstances - to access the products and services that are being marketed.

\footnotetext{
${ }^{1}$ Annika Berg, Den gränslösa hälsan. Signe och Axel Höjer, folkhälsan och expertisen (Uppsala: Uppsala universitet, 2009); Yvonne Hirdman, Att lägga livet tillrätta. Studier i svensk folkhemspolitik (Stockholm: Carlsson, 1989); Helena Hörnfeldt, Prima barn, helt u.a. Normalisering och utvecklingstänkande i svensk barnhälsovård 1923-2007 (Göteborg: Makadam, 2009); Karin Johannisson, Kroppens tunna skal. Sex essäer om kropp, historia och kultur (Stockholm: Norstedt, 1997); Ulf Olsson, Drömmen om den hälsosamma medborgaren (Stockholm: Carlsson, 1999); Eva Palmblad and Bengt Erik Eriksson, Kropp och politik: Hälsoupplysning som samhällsspegel från 30- till 90-tal (Stockholm, Carlsson, 1995).
} 
${ }^{2}$ Allan M. Brandt and Paul Rozin, eds., Morality and Health (New York: Routledge, 1997), 65-70; Olsson, Drömmen om den hälsosamma; Palmblad and Eriksson, Kropp och politik; Dorothy Porter, 'The social contract of health in the twentieth and twenty-first centuries: Individuals, corporations, and the state', in Shifting Boundaries of Public Health: Europe in the Twentieth Century, ed. Susan Gross Solomon et al. (Woodbridge: Boydell \& Brewer, 2008), 46-47; Arttu Saarinen, Suvi Salmenniemi and Harri Keränen, 'Hyvinvointivaltiosta hyvinvoivaan valtioon. Hyvinvointi ja kansalaisuus suomalaisessa poliittisessa diskurssissa', Yhteiskuntapolitiikka 79, no. 6 (2014): 605-618.

${ }^{3}$ Karin Johannisson, 'The people's health: Public health policies in Sweden', in The History of Public Health and the Modern State, ed. Dorothy Porter (Amsterdam: Editions Rodopi B.V., 1994), 165-182, 178, 179.

${ }^{4}$ Susan K. Cahn, Coming on Strong: Gender and Sexuality in Twentieth-Century Women's Sport (New York, Harvard University Press, 1995); Jennifer Hargreaves, Sporting Females: Critical Issues in the History and Sociology of Women's Sports (London, Routledge, 1994); Helena Tolvhed, På damsidan. Femininitet, motstånd och makt $i$ svensk idrott 1920-1990 (Göteborg, Makadam förlag, 2015).

${ }^{5}$ Such as Voi hyvin (1982-), iForm (1987-), Hälsorevyn (1987-1990), KuntoPlus (1988-), B \& K sports magazine (1989-, today Body), Hyvä Terveys (1993-), Sport (2002-), Topphälsa (2004-), Body (2005-), Fit (2008-), LCHFmagasinet (2010-), Fitness Magazine (2001-, today Women's Health Sverige), Hälsa \& Fitness (2011-), Apu Terveys (2014-), ET terveys (2014-). The magazine market has pluralised, overall, but health and training magazines have wide circulation. In Finland, for example, Hyvä Terveys had the third highest circulation among all magazines in 2016 (Aku Ankka and ET-lehti had higher circulation). Kansallinen Mediatutkimus (KMT), 'KMT 2016 lukijamäärät ja kokonaistavoittavuus', MediaAuditFinland, http://mediaauditfinland.fi/wp-content/uploads/2017/03/KMT-2016lukijamaarat.pdf (accessed 21.3.2017).

${ }^{6}$ Robert Crawford, 'Healthism and the medicalization of everyday life', International Journal of Health Services 10 , no. 3 (1980): 365-388; Alan Peterson and Deborah Lupton, The New Public Health. Health and Self in the Age of Risk (London: Sage, 1996).

${ }^{7}$ See also the introductory chapter in this volume.

${ }^{8}$ Michel Foucault, Discipline and Punish: The Birth of the Prison (New York: Pantheon Books, 1977); Michel Foucault, 'Body/Power', in Michel Foucault: Power/Knowledge, ed. Colin Gordon (New York: Pantheon Books, 1980).

${ }^{9}$ Nikolas Rose, Powers of Freedom. Reframing Political Thought (Cambridge: Cambridge University Press, 1999), 86-87.

${ }^{10}$ Neo-liberalism was born in Anglo-American cultures, but the ideology has influenced the Nordic welfare societies as well. The change towards neo-liberal values might have been slower, but similar debates about 'bureaucratic' state systems and 'efficient' competition models has been introduced to Nordic political sphere since late twentieth century. See, for example, Jason Read, 'A genealogy of homo-economicus: Neoliberalism and the production of subjectivity', Foucault Studies, no. 6 (2009): 25-26; Saarinen et al. 'Hyvinvointivaltiosta'.

${ }^{11}$ Nikolas Rose, 'Government and control', British Journal of Criminology 40, no. 2 (2000): 321-339, 337.

${ }^{12}$ Erika Björklund, Constituting the Healthy Employee? Governing Gendered Subjects in Workplace Health Promotion (Umeå: Umeå universitet, 2008); Shari L. Dworkin and Faye Linda Wachs, Body Panic. Gender, Health, and the Selling of Fitness (New York: New York University Press, 2009); Kathleen LeBesco, 'Neoliberalism, public health, and the moral perils of fatness', Critical Public Health 21, no. 2 (2011): 153-164; Petersen and Lupton, New Public Health, 68-69; Helena Sandberg, Medier \& fetma. En analys av vikt. (Lund, Sociologiska institutionen, 2004).

${ }^{13}$ Chris Shilling, The Body and Social Theory (London: SAGE Publications, 1993), 4-8, 199-200.

${ }^{14}$ Carl Cederström and André Spicer, The Wellness Syndrome (Cambridge: Polity, 2015).

15 Jesper Andreasson and Thomas Johansson, Fitnessrevolutionen. Kropp, hälsa och gymkulturens globalisering (Stockholm: Carlssons, 2015), 59; Dworkin and Wachs, Body Panic, 1-3, 10; Christina Hedblom, The Body Is Made to Move: Gym and Fitness Culture in Sweden (Stockholm: Acta Universitatis Stockholmiensis, 2009).

${ }^{16}$ The gym and fitness industry has been expanding steadily, mainly in the Western world but also in countries such as Brazil, Japan and China. Andreasson and Johansson, Fitnessrevolutionen; M. J. Stern, 'The fitness movement and the fitness center industry, 1960-2000', Business and Economic History On-line 6, no. 1 (2008).

${ }^{17}$ Kasper Lund Kirkegaard, Fitnesskultur.dk - fitness-sektorens historie, de aktive udфvere og breddeidrattens kommercialisering (Odense: Syddansk universitet, 2011), 182, 206-209.

${ }^{18}$ Foucault (Discipline and Punish) emphasises the role of knowledge in body governance: borders of society and humanity are formed, defended and renegotiated in practices of knowledge and power. 
${ }^{19}$ Norman Fairclough, Media Discourse (London: Edward Arnold, 1995); Sara Mills, Discourse (London: Routledge, 2004); Diane Negra and Yvonne Tasker, 'Gender and recessionary culture', in Gendering the Recession: Media and Culture in an Age of Austerity, ed. Diane Negra and Yvonne Tasker (Durham: Duke University Press, 2014), 1-2.

${ }^{20}$ The title of the magazine has changed during the years: 1940-1944: Solvikingen; 1944-1953: Waerlands månadsmagasin: tidskrift för hälsa; 1953-1978: Tidskrift för hälsa; 1978-: Hälsa.

${ }^{21}$ The journal Hälsovännen existed 1886-1961, but was more orientated towards medicine and sanitation.

${ }^{22}$ See, e.g., 'Vad har DU med miljövård att göra?', Tidskrift för hälsa, no. 1 (1970): 28-31.

${ }^{23}$ Johan Börtz, 'Vetenskapliga höns', Tidskrift för hälsa, no. 3 (1960): 9; Tidskrift för hälsa no. 5 (1960): 7.

${ }^{24}$ Alf Ahlberg, 'Allt det vi inte behöver finns att köpa', Tidskrift för hälsa, no. 1 (1970): 16-17.

${ }^{25}$ Richard Jobson: 'Krigsförklaring mot fredlig atomkraft', Tidskrift för hälsa, no. 4 (1970): 11.

${ }^{26}$ Lennart Warodell, ‘1960 - ett hälsofrämjande år', Tidskrift för hälsa, no. 1 (1960): 21.

${ }^{27}$ With the exception of an article on the upcoming vote on nuclear power in March 1980, where the no-alternative was advocated as the better choice for health and future, Tidskrift för hälsa, no. 3 (1980): 14-17.

${ }^{28}$ Tidskrift för hälsa, no. 1 (1990).

${ }^{29}$ A similar point has been made by Kardemark in a study of Swedish health journals at two points in time: 19101913 and 2009. Wilhelm Kardemark, När livet tar rätt form. Om människosyn i svenska hälsotidskrifter 1910-13 och 2009 (Göteborg: Göteborgs universitet 2013).

${ }^{30}$ Karin Johannisson, 'Den undflyende hälsan: hälsostrategier i Sverige under 1900-talet', in I väntan på framtiden. Rapport från forskarseminariet i Umeå januari (Stockholm: Försäkringskasseförbundet, 2000), 38-49; Charlotte Macdonald, Strong, Beautiful and Modern. National Fitness in Britain, New Zealand, Australia and Canada, 1935 1960 (Vancouver: University of British Columbia Press, 2013); Porter, 'Social contract of health'; Malin Österlind and Jan Wright, 'If sport's the solution then what's the problem? The social significance of sport in the moral governing of "good" and "healthy" citizens in Sweden, 1922-1998', Sport, Education and Society 19, no. 8 (2014): 973-990, 986.

${ }^{31}$ Wendy Brown, Edgework: Critical Essays on Knowledge and Politics (Princeton, NJ: Princeton University Press, 2005).

${ }^{32}$ Saarinen et al., 'Hyvinvointivaltiosta', 615.

${ }^{33}$ Jallinoja and Suihko have studied the values related to nutrition discussions in Sotilaskoti, a Finnish magazine published by a voluntary service to provide free-time spaces, or military homes, for soldiers. This magazine, obviously, differs from some other commercial health magazines, but provides some information about the Finnish magazines. Piia Jallinoja and Johanna Suihko, 'Munkkiperinteestä pizzaelämykseen - Terveys ja ruoka sotilaskotilehdessä 1967-2007', Tiedotustutkimus 30, no. 4 (2007): 41-43.

${ }^{34}$ Pertti Suhonen, 'Suomalaisten eriytyvät ja muuttuvat arvot', in Uskonto, arvot ja instituutiot. Suomalaiset World Values -tutkimuksissa 1981-2005, ed. Sami Borg et al. (Tampere: Yhteiskuntatieteellinen tietoarkisto, 2007$), 40$.

35 The mortality rate is a measure of the number of deaths in a particular population and is typically expressed in units of deaths per 1,000 persons per year. Because the rate is scaled to the size of the population and often used in relation to a specific cause of death, the rates become comparable.

${ }^{36}$ Life expectancy is a statistical measure of how long a person may live based on the year of their birth.

${ }^{37}$ Nikolas Rose and Carlos Novas, 'Biological citizenship', in Global Assemblages: Technology, Politics, and Ethics as Anthropological Problems, ed. Aihwa Ong \& Stephen J. Collier (Oxford: Blackwell Publishing, 2004), $439-463$.

${ }^{38}$ See also, Katariina Kyrölä, The Weight of Images. Affect, Body Image and Fat in the Media (Farnham, Burlington: Ashgate, 2014), 31-92.

39 'Karu totuus: Kaikki liikakilot lyhentävät elinikää - katso pienimmän riskin painoindeksi!', Ilta-Sanomat 19.5.2016.

40 ‘Hyviä uutisia! Pari tuntia liikuntaa viikossa riittää jo pidentämään elinikää', Ilta-Sanomat 14.4.2015.

${ }^{41}$ Ulla Järvi, “"Suomalaistutkijat tekivät mullistavan havainnon” - analyysi vuoden 2004 terveysaiheisista tiedotteista', Tiedotustutkimus 30, no. 4 (2007): 53-60.

${ }^{42}$ This approach, which often invokes or utilises feelings of guilt and blame, is a visible trait in some of the health journalism in Finland. For example, STT, the Finnish News Agency, wrote an announcement how the overweight issues costs 300 million euros a year to Finnish health care. STT 8.7.2010. 
43 'Nuorten suomalaisnaisten syöpätilastossa hyppäys - 'Uudenmaan ja Etelä-Suomen ilmiö', Ilta-Sanomat 20.4.2016.

44 'Lapsuuden lihavuus lyhentää elämää', Iltalehti 23.2.2010.

45 'Yli 65-vuotias: Nämä 4 asiaa tuovat sinulle 10 vuotta lisää elinaikaa', Ilta-Sanomat 27.7.2014.

46 'Luja kädenpuristus pidentää elinikää', Iltalehti 22.9.2010.

${ }^{47}$ Petersen and Lupton, New Public Health, 27. See also Johannes Kananen's contribution in this volume.

${ }^{48}$ Petersen and Lupton, New Public Health, 27-60.

${ }^{49}$ Dworkin and Wachs, Body Panic.

50 The press material from 2017 as written in the marketing pages of Finnish magazine platform. Aikakausmedia, 'Jäsenluettelo', http://www.aikakauslehdet.fi/jasenet/?lista=lehdet (accessed 21.3.2017).

${ }^{51}$ Kirkegaard, Fitnesskultur.dk, 27, 40-41, 186, 194-195.

${ }^{52}$ Dworkin and Wachs, Body Panic; Angela McRobbie, The Aftermath of Feminism: Gender, Culture and Social Change (London: Sage, 2009); Jennifer Smith Maguire, Fit for Consumption: Sociology and the Business of Fitness (Abingdon: Routledge, 2007).

${ }^{53}$ Helena Tolvhed, 'Hälsosam femininitet och postfeministiska subjekt. En undersökning av hälso- och träningsmagasinet iForm 1987, 1997 och 2007', Tidskrift för genusvetenskap 37, no. 3 (2016): 77-94.

${ }^{54}$ Kerry R. McGannon and John C. Spence, ‘Exploring news media representations of women’s exercise and subjectivity through critical discourse analysis', Qualitative Research in Sport, Exercise and Health 4, no 1 (2012): 32-50, 36, 46; Tolvhed, 'Hälsosam femininitet'.

${ }^{55}$ Christy Newman, 'Reader letters to women's health magazines. Inscribing the "Will to Health", Feminist Media Studies 7, no. 2 (2007): 155-170, 163.

${ }^{56}$ Annemarie Jutel and Stephen Buetow, 'A picture of health? Unmasking the role of appearance in health', Perspectives in Biology and Medicine 50, no. 3 (2007): 421-434; Chris Shilling, The Body and Social Theory (London: Sage, 2003).

57 The concept of 'mediatisation' addresses the changing logic of media that influences everyday practices, experiences and communication of (health) issues. Andrear Hepp, 'Differentiation: Mediatization and cultural change', in Mediatization: Concept, Changes, Consequences, ed. Knut Lundby (New York: Peter Lang Publishing, 2009), 139-158; Stig Hjarvard, The Mediatization of Culture and Society (London, New York: Routledge, 2013); Friedrich Krotz, 'Mediatization: A concept with which to grasp media and societal change', in Mediatization: Concept, Changes, Consequences, ed. Knut Lundby (New York: Peter Lang Publishing, 2009), 21-40.

${ }^{58}$ Peterson and Lupton, New Public Health, xiii, xiv.

${ }^{59}$ Brown, Edgework; Saarinen et al., 'Hyvinvointivaltiosta', 604, 612-614. 